
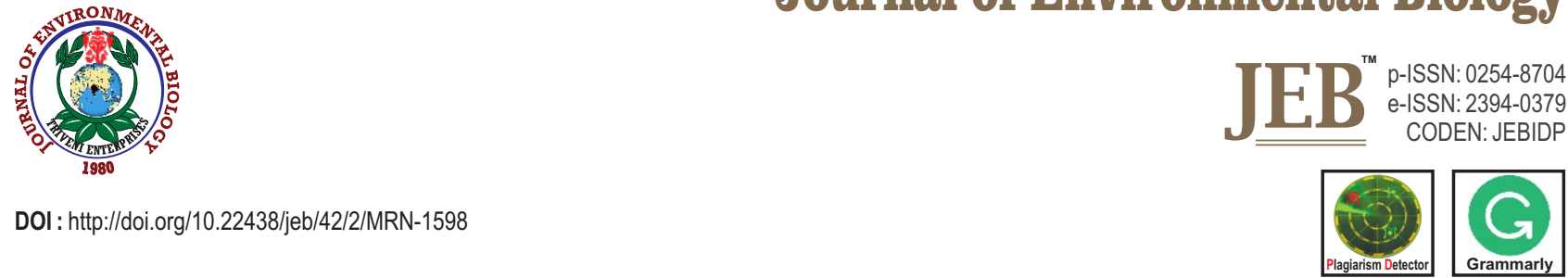

\title{
Impact of zinc fertilization on growth, yield and quality of zero till wheat (Triticum aestivum L.)
}

\author{
M. Singh ${ }^{1 *}$ and K.S. Sandhu ${ }^{2}$ \\ ${ }^{1}$ Faculty of Agricultural and Forestry, Guru Nanak Dev University, Amritsar-143002, India \\ ${ }^{2}$ Department of Agriculture, Khalsa College, Amritsar-143 002, India \\ *Corresponding Author Email : mandeepsingh283@yahoo.com
}

\section{Abstract}

Aim: To determine the impact of soil and foliar application of $\mathrm{ZnSO}_{4} \cdot 7 \mathrm{H}_{2} \mathrm{O}$ at late stages of wheat as heading initiation ( $5 \%$ ear formation), $100 \%$ heading (complete ear formation) and heading initiation and $100 \%$ heading along with recommended dose of fertilizer on growth, yield and quality of zero till wheat.

Methodology: The field experiment was conducted on zero till wheat. The treatments consisted of control (no $\mathrm{Zn})$, soil application of $12.5,25,37.5,50 \mathrm{~kg} \mathrm{ha}^{-1}$ $\mathrm{ZnSO}_{4} \cdot 7 \mathrm{H}_{2} \mathrm{O}$ and foliar application of $0.5 \% \mathrm{Zn}$ as one spray at heading initiation ( $5 \%$ ear formation), one spray at $100 \%$ heading (complete ear formation) and two sprays at heading initiation and $100 \%$ heading with recommended dose of fertilizer. These treatments were evaluated in RBD with three replications.

Results: Soil application of 50, 37.5 and $25 \mathrm{~kg} \mathrm{Zn} \mathrm{ha}^{-1}$ with two foliar sprays of $0.5 \%$ at heading initiation ( $5 \%$ ear formation) and 100\% heading (complete ear formation) stages gave significantly higher average grain and straw yield and $\mathrm{Zn}$ concentration in grain than other treatments, including control.

Interpretation: Enhanced application of $\mathrm{Zn}$ as soil and foliar application ameliorates soil Zn deficiency and increases protein content in grains, which might influence the quality and yield of zero tilled wheat.

Key words: Foliar spray, Grain yield, Wheat, Zinc

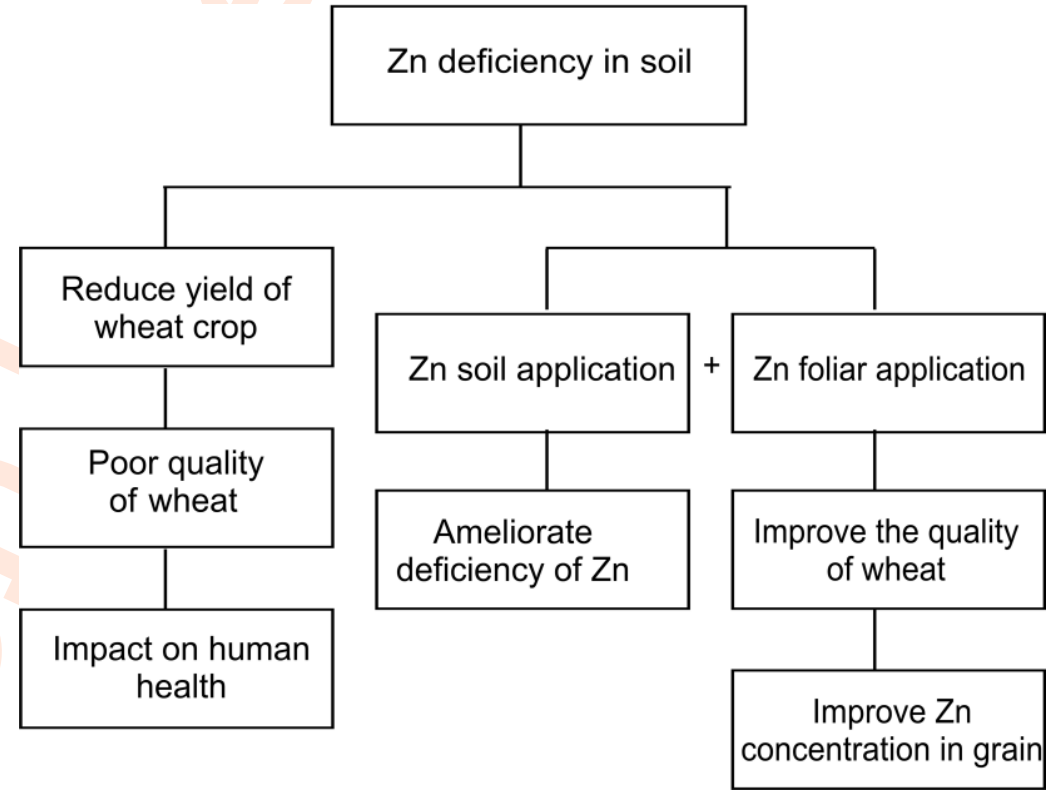
331 (2021). 


\section{Introduction}

Wheat is a major cereal crop and source for dietary calorie intake, protein and micro-nutrients mostly in the developing countries, accounting $50 \%$ of the daily calories intake (Cakmak, 2008). Production of food grains is increasing year after year due to intensive cultivation of land, thereby depleting a huge amount of macronutrients along with micronutrients. Though, the requirement of micronutrients for different crops is less than the macronutrients but they play a pivotal role in influencing the yields and quality of grains. Zinc deficiency is prevalent in wheat growing areas both in temperate and tropical climates (Shivay et al., 2008). As per report of Takkar (1996), about 47\% of Indian soils are deficient of $\mathrm{Zn}$ content, which leads to decline in wheat yields in countries like India, Australia and Turkey. The soils of Punjab are also suffering from sizeable amount of $Z n$ deficiency $(22.6 \%)$, which is considerably enough to adversely affect the yield of food crop in the state (Tiwana et al., 2007).

Zinc deficiency is among the top five micronutrient deficiencies severely affecting one-third of world's population, especially rural communities (Stein, 2010). Micronutrient malnutrition is a global health problem affecting more than 3 billion people world wide (Cakmak et al., 2010). About 44\% children less than five years of age are zinc deficient in India (Kapil and Jain, 2011). Under severely $\mathrm{Zn}$ deficient soils, the $\mathrm{Zn}$ concentration of wheat grains may be as low as $10 \mathrm{mg} \mathrm{kg}^{-1}$, whereas the human requirement is $40-60 \mathrm{mg} \mathrm{kg}^{-1}$ and the current situation for world is 10 $30 \mathrm{mg} \mathrm{kg}^{-1}$ (Cakmak et al., 2010). Inadequate intake of food low in zinc content is a major contributor to the prevalence of zinc deficiency in humans. Zn deficiency significantly affects human health leading to reduced growth and immunity, learning deficits, mental retardation and DNA damage (Prasad, 2008).

Biofortification is the process of increasing natural content of nutrients in edible part of crop plants (Welch, 2005). The supply of minerals to the developing cereal grain originates from two sources: first as a result of direct uptake from the soil and second from remobilization of stored minerals in leaves as they senesce during grain filling stage. Agronomic biofortification of Zn involves fertilizer application by soil and foliar application. Soil application of zinc sulphate before sowing is the most common approach to correct $Z n$ deficiency in crops (Alloway, 2008). But foliar Zn application is also used, usually at mid tillering or at early anthesis stages (Cakmak et al., 2010 a). Foliar application of Zn seems to be an effective method of ameliorating $Z n$ deficiency and a useful method for enhancing $\mathrm{Zn}$ concentration in grain. Moreover, the fertilizer technique is a quick and complementary strategy, which maintains and builds a pool of zinc for translocation and uptake. The timing of foliar spray of micronutrients is an important factor determining its effectiveness in increasing grain enrichment of microelements. The large increase in zinc grain concentration are most likely when foliar Zn fertilizers are applied to late growth stages of wheat as heading initiation, $100 \%$ heading, milk stage or dough stage etc. Ozturk et al. (2006) studied changes in grain Zn concentration in wheat and found the highest concentration of grain Zn occurs during the milk stage of grain development. Different reports are available indicating that more than $50 \%$ of wheat around the globe is cultivated on zinc-deficient soils (Alloway, 2004; Cakmak, 2008), which further lower grain zinc content. In response to aforementioned problem, different approaches have been suggested in developing nation, where biofortification of cereals with important micronutrient is receiving a great deal of attention. Keeping in view the above, the present study was planned with soil application before sowing and foliar application at heading initiation (5\% ear formation) and 100\% heading (complete ear formation) with recommended fertilizer to determine their impacts on growth, yield and quality of zero till wheat.

\section{Materials and Methods}

Experimental site and weather conditions: $A$ field experiment was conducted during Rabi season of 2018-19 and 2019-20 at the Research Farm Area of Post Graduate Department of Agriculture, Khalsa College, Amritsar. This site has hot moist and semi-arid type of climate with alluvial, medium available water holding capacity soils. The mean values of minimum and maximum temperature recorded during growing seasons of zero till wheat ranged from 10.2 to $25.2^{\circ} \mathrm{C}$ and 10.9 to $24.0^{\circ} \mathrm{C}$, respectively. The value of minimum to maximum relative humidity during both growing seasons of wheat was 38 to $94 \%$ and 39 to $91 \%$, respectively. The average sunshine hours during growing season of wheat ranged from 5.1 to $6.1 \mathrm{hr} \mathrm{day}^{-1}$ while total amount of rainfall was 181 and $253 \mathrm{~mm}$, respectively. The soil of the field was sandy loam, having a pH 7.2, EC $0.13 \mathrm{dS} \mathrm{m}^{-1}$, low in organic carbon $(0.31 \%)$, available nitrogen $\left(248 \mathrm{~kg} \mathrm{ha}^{-1}\right)$, medium in phosphorus (17.8 $\left.\mathrm{kg} \mathrm{ha}^{-1}\right)$ and available potassium $\left(275 \mathrm{~kg} \mathrm{ha}^{-1}\right)$.

The available $\mathrm{Zn}$ in soil was below critical level $(0.57 \mathrm{mg}$ $\left.\mathrm{kg}^{-1}\right)$. The $\mathrm{pH}$ was measured using $1: 2$ soil and water suspension, organic carbon by Walkley and Black's Rapid Titration Method and available potassium using with Ammonium Acetate Extractable K Method (Jackson, 1967), available nitrogen and phosphorus was determined by Alkaline Potassium Permanganate Method (Subbiah and Asija, 1956) and Sodium Bicarbonate Extractable Method (Olsen et al., 1954), respectively. DTPA-extractable Zn content was determined with AAS FS 240 Model of Atomic Absorption Spectrophotometer. For estimation of $\mathrm{Zn}$ content in grain, $0.5 \mathrm{~g}$ grain sample was digested in diacid mixture of $\mathrm{HNO}_{3}: \mathrm{HClO}_{4}$ (Page et al., 1982). After proper dilution with double distilled water, the $\mathrm{Zn}$ content in digested materials was estimated on Atomic Absorption Spectrophotometer (VarianAAS FS 240 Model).

Experimental details: The field experiment consisted of thirteen treatments, viz $\mathrm{T}_{1}$ - control (no Zn), $\mathrm{T}_{2}-12.5 \mathrm{~kg} \mathrm{Zn} \mathrm{ha}{ }^{-1}+0.5 \%$ foliar spray at heading initiation, $T_{3}-12.5 \mathrm{~kg} \mathrm{Zn} \mathrm{ha}^{-1}+0.5 \%$ foliar spray at $100 \%$ heading initiation, $T_{4}-12.5 \mathrm{~kg} \mathrm{Zn} \mathrm{ha}^{-1}+0.5 \%$ foliar spray at heading initiation and $100 \%$ heading, $\mathrm{T}_{5^{-}} 25 \mathrm{~kg} \mathrm{Zn} \mathrm{ha}{ }^{-1}+0.5 \%$ foliar spray at heading initiation, $\mathrm{T}_{6}-25 \mathrm{~kg} \mathrm{Zn} \mathrm{ha}{ }^{-1}+0.5 \%$ foliar 
spray at $100 \%$ heading, $\mathrm{T}_{7}-25 \mathrm{~kg} \mathrm{Zn} \mathrm{ha-1}+0.5 \%$ foliar spray at heading initiation and $100 \%$ heading, $\mathrm{T}_{8}-37.5 \mathrm{~kg} \mathrm{Zn} \mathrm{ha}{ }^{-1}+0.5 \%$ foliar spray at heading initiation, $\mathrm{T}_{9}-37.5 \mathrm{~kg} \mathrm{Zn} \mathrm{ha}{ }^{-1}+0.5 \%$ foliar spray at $100 \%$ heading, $T_{10}-37.5 \mathrm{~kg} \mathrm{Zn} \mathrm{ha-1}+0.5 \%$ foliar spray at heading initiation and $100 \%$ heading, $T_{11}-50 \mathrm{~kg} \mathrm{Zn} \mathrm{ha}^{-1}+0.5 \%$ foliar spray at heading initiation, $\mathrm{T}_{12}-50 \mathrm{~kg} \mathrm{Zn} \mathrm{ha-1}+0.5 \%$ foliar spray at $100 \%$ heading, $\mathrm{T}_{13}-50 \mathrm{~kg} \mathrm{Zn} \mathrm{ha-1}+0.5 \%$ foliar spray at heading initiation and $100 \%$ heading. The treatments were evaluated in randomized block design with three replications. Zinc was applied as per the treatments, except for control.

Zinc $\left(\mathrm{ZnSO}_{4} \cdot 7 \mathrm{H}_{2} \mathrm{O}\right)$ was applied before sowing of the crop, foliar sprays of $0.5 \%$ zinc sulfate heptahydrate were applied at heading initiation (5\% ear formation), 100\% heading (complete ear formation), initiation, and $100 \%$ heading stages of the crop vegetative growth during evening hours. During both years wheat variety of Unnat PBW 343 was sown in the first week of November using $100 \mathrm{~kg}$ seed ha-1 under zero till conditions (without seed bed preparation) at $22.5 \mathrm{~cm}$ row spacing using zero till seed drill in combined harvested rice field in standing stubbles after removing the loose rice straw from the field. Nitrogen was applied @ $125 \mathrm{~kg} \mathrm{ha}^{-1}$ as urea in two splits (1/2 at the time of sowing and $1 / 2$ after first irrigation). Phosphorus was applied @ $62.5 \mathrm{~kg} \mathrm{ha}^{-1}$ and potassium @ $30 \mathrm{~kg} \mathrm{ha}^{-1}$ as full basal dose at the time of sowing with zero till seed drill.

All the other recommended package of practices of Punjab Agricultural University was followed for successful raising of zero till wheat. Harvested crop produce from net plot was threshed manually by beating on hard surface. The grain yield was recorded in $\mathrm{kg}$ per plot and expressed in tha ${ }^{-1}$. Bundle weight was taken before threshing and straw weight $(\mathrm{kg})$ was recorded after deducting grain weight $(\mathrm{kg})$ from the bundle weight $(\mathrm{kg})$, which was straw yield, expressed in $\mathrm{t} \mathrm{ha-1}$. Biological yield was calculated by the sum of grain and straw yield. Zn uptake was calculated by multiplying the percent of $\mathrm{Zn}$ content of grain and straw with their respective yield.

Analysis of quality parameters: The grain protein content was estimated using whole grain analyzer Infratec 1241. The instrument uses the near infrared light transmitted through the grains. The results are displayed as \% protein content as per calibration. The sodium dodecyl sulphate sedimentation value of whole meal samples was estimated by the method of Axford et al. (1979). A sample weight of $6 \mathrm{~g}$ and a rest period of 20 minutes were employed. Hectolitre weight was measured using the apparatus developed by the Directorate of Wheat Research, Karnal, which employs a standard container of $100 \mathrm{ml}$ capacity. The grains were weighed and the hectolitre weight was expressed in $\mathrm{kg} \mathrm{hl}^{-1}$. The grain appearance score was based on the size, shape, color and luster of the grain. It was evaluated subjectively out of a maximum score of 10 . Beta carotene content was determined using water saturated butanol to extract beta carotene pigment. Absorbance of the filtrate was measured at $440 \mathrm{~nm}$ using UV-VIS Spectrophotometer using water saturated butanol as blank. The beta carotene content was calculated as follows: Beta carotene $(\mathrm{ppm})=0.0105+23.5366 \times$ Optical Density (O.D.).

Statistical analysis: The data obtained from two year study were analyzed statistically as per the procedure given by Gomez and Gomez (1984) using CPCS1 software. LSD values at $P=0.05$ were used to determine significance between different treatments.

\section{Results and Discussion}

Grain, straw and biological yield of zero till wheat responded significantly to soil and foliar application of $\mathrm{ZnSO}_{4} \cdot 7 \mathrm{H}_{2} \mathrm{O}$ at later stages (Table 1). However, the highest average grain yield, straw and biological yield was recorded with $T_{13}$ treatment, which was at par with $T_{10}$ and $T_{7}$ treatment. These treatments gave significantly higher grain, straw and biological yield as compared to other treatments, which was $33.16,31.37$ \& $25.51,34.95,30.60 \& 24.00$ and $34.22,30.71 \& 24.81 \%$ higher than control. Therefore, $\mathrm{T}_{7}$ treatment gave significantly similar average grain, straw and biological yield as compared to higher level of $\mathrm{Zn}$ treatments, so this treatment can be used to obtain higher grain and straw yield of zero till wheat in $\mathrm{Zn}$ deficient sandy loam soil. The results are in conformity with the findings of Narwal et al. (2010) who recorded the maximum increase in grain yield when $\mathrm{ZnSO}_{4}$ of $25 \mathrm{~kg} \mathrm{ha}^{-1}$ was applied as soil application and $0.5 \%$ of $\mathrm{ZnSO}_{4}$ as foliar spray. However, Afzal et al. (2017) observed the highest grain yield (6.00 $\left.\mathrm{tha}^{-1}\right)$ and biological yield (11.93 $\mathrm{t} \mathrm{ha}^{-1}$ ) with soil application of $\mathrm{Zn}$ before planting and foliar application at later stages of growth.

Similar findings were reported by some other workers as the highest grain and biomass yield with the addition of $20 \mathrm{~kg}$ $\mathrm{Zn} \mathrm{ha}{ }^{-1}$ and foliar application of zinc $(0.5 \%)$ at heading and milking stage (Vora et al., 2019; Pallavi and Sudha, 2017; ElDahshouri et al., 2017). Zinc increases photosynthesis, initial growth, nitrogen fixation, which resulted in higher biological yield. Whereas, Imran and Rehim (2016) reported that combined application of $\mathrm{Zn}$ (soil + foliar) is more promising in improving plant growth and yield than other fertilization approaches. The increase application growth and yields of zero till wheat with application of $\mathrm{Zn}$ might be due to the enzymatic functions, pollination and grain development with translocation and synthesis of carbohydrates in grains due to $\mathrm{Zn}$ fertilization. $\mathrm{Zn}$ also play an important role in chlorophyll biosynthesis, maintenance of photosynthetic activity and biosynthesis of auxin, which regulates remobilization of carbohydrate to grain, providing an improved resource generating base for the crop.

$\mathrm{Zn}$ concentration in grains and straw of zero till wheat increased significantly with different rates of $\mathrm{Zn}$ treatment (Table 2). The highest concentrations of $Z n$ was recorded in grain (41.77 mg kg${ }^{-1}$ ) with $T_{13}$ treatment, which was $33.92 \%$ higher over the control $\left(31.19 \mathrm{mg} \mathrm{kg}^{-1}\right)$. The higher concentration of $\mathrm{Zn}$ in grain was found with treatment $T_{13}$, which was at par with $T_{10}$ and $T_{7}$, and was 32.38 and $30.81 \%$ higher than control. Similar trend in $\mathrm{Zn}$ 
Table 1: Effect of zinc application on yield of zero till wheat (Pooled data of two years)

\begin{tabular}{|c|c|c|c|c|c|c|}
\hline Treatments & $\begin{array}{l}\text { Grain yield } \\
\left(\mathrm{t} \mathrm{ha}^{-1}\right)\end{array}$ & $\begin{array}{l}\% \text { increase } \\
\text { over the control }\end{array}$ & $\begin{array}{l}\text { Straw yield } \\
\left(\mathrm{t} \mathrm{ha}^{-1}\right)\end{array}$ & $\begin{array}{l}\% \text { increase } \\
\text { Over the control }\end{array}$ & $\begin{array}{l}\text { Biological } \\
\text { yield }\left(\mathrm{t} \mathrm{ha}^{-1}\right)\end{array}$ & $\begin{array}{l}\% \text { increase Over } \\
\text { the control }\end{array}$ \\
\hline $\mathrm{T}_{1}$ & 3.92 & - & 5.75 & - & 9.67 & - \\
\hline $\mathrm{T}_{2}$ & 4.07 & 3.82 & 6.02 & 4.69 & 10.09 & 4.34 \\
\hline $\mathrm{T}_{3}$ & 4.18 & 6.63 & 6.15 & 6.95 & 10.33 & 6.82 \\
\hline $\mathrm{T}_{4}$ & 4.31 & 9.94 & 6.47 & 12.52 & 10.78 & 11.47 \\
\hline $\mathrm{T}_{5}$ & 4.51 & 15.05 & 6.84 & 18.95 & 11.35 & 17.37 \\
\hline $\mathrm{T}_{6}$ & 4.66 & 18.87 & 7.08 & 23.13 & 11.74 & 21.40 \\
\hline $\mathrm{T}_{7}$ & 4.92 & 25.51 & 7.15 & 24.00 & 12.07 & 24.81 \\
\hline $\mathrm{T}_{8}$ & 4.72 & 20.41 & 6.89 & 19.83 & 11.61 & 21.69 \\
\hline $\mathrm{T}_{9}$ & 4.80 & 22.45 & 6.99 & 21.56 & 11.79 & 21.92 \\
\hline $\mathrm{T}_{10}$ & 5.13 & 31.37 & 7.51 & 30.60 & 12.64 & 30.71 \\
\hline$T_{11}$ & 4.82 & 22.96 & 7.04 & 22.43 & 11.86 & 22.64 \\
\hline $\mathrm{T}_{12}$ & 4.88 & 24.49 & 7.07 & 22.96 & 11.95 & 23.57 \\
\hline $\mathrm{T}_{13}$ & 5.22 & 33.16 & 7.76 & 34.95 & 12.98 & 34.22 \\
\hline S. Em \pm & 0.11 & - & 0.21 & - & 0.29 & - \\
\hline $\operatorname{LSD}(P=0.05)$ & 0.32 & - & 0.62 & - & 0.92 & - \\
\hline
\end{tabular}

Table 2: Effect of zinc application on grain quality parameters of zero till wheat (Pooled data of two years)

\begin{tabular}{llllll}
\hline Treatments & $\begin{array}{l}\text { Zn content in } \\
\text { grain }\left(\mathbf{m g ~ k g}^{-1}\right)\end{array}$ & $\begin{array}{l}\text { \% increase } \\
\text { over the control }\end{array}$ & $\begin{array}{l}\text { Zn content in } \\
\text { straw }\left(\mathbf{m g ~ k g}^{-1}\right)\end{array}$ & $\begin{array}{l}\text { Total Zn } \\
\text { uptake }\left(\mathbf{g ~ h a}^{-1}\right)\end{array}$ & $\begin{array}{l}\text { Protein } \\
\text { content }(\%)\end{array}$ \\
\hline $\mathrm{T}_{1}$ & 31.19 & 0 & 18.15 & 226.62 & 11.49 \\
$\mathrm{~T}_{2}$ & 32.67 & 4.74 & 20.00 & 253.36 & 11.62 \\
$\mathrm{~T}_{3}$ & 33.01 & 5.83 & 20.21 & 262.27 & 11.65 \\
$\mathrm{~T}_{4}$ & 33.32 & 6.82 & 20.41 & 275.66 & 11.68 \\
$\mathrm{~T}_{5}$ & 35.12 & 12.60 & 21.16 & 303.12 & 11.84 \\
$\mathrm{~T}_{6}$ & 35.81 & 14.81 & 22.20 & 324.05 & 11.90 \\
$\mathrm{~T}_{7}$ & 40.80 & 30.81 & 24.31 & 374.55 & 12.34 \\
$\mathrm{~T}_{8}$ & 38.75 & 24.23 & 23.06 & 341.78 & 12.15 \\
$\mathrm{~T}_{9}$ & 39.17 & 25.58 & 23.30 & 350.88 & 12.21 \\
$\mathrm{~T}_{10}$ & 41.29 & 32.38 & 24.29 & 394.23 & 12.40 \\
$\mathrm{~T}_{11}$ & 39.81 & 27.63 & 23.74 & 359.01 & 12.18 \\
$\mathrm{~T}_{12}$ & 40.04 & 28.37 & 23.99 & 365.00 & 12.20 \\
$\mathrm{~T}_{13}$ & 41.77 & 33.92 & 24.52 & 408.31 & 12.53 \\
$\mathrm{~S} . \mathrm{Em} \pm$ & 0.38 & - & 0.09 & 11.62 & 0.07 \\
$\mathrm{LSD}(\mathrm{P}=0.05)$ & 1.14 & - & 0.24 & 33.84 & 0.23 \\
\hline
\end{tabular}

concentration in straw was recorded as $\mathrm{Zn}$ concentration present in grains. It was affected statistically with the various $\mathrm{Zn}$ treatments but it increased with all treatments over the control. The range $Z n$ varied from 24.52 to $18.15 \mathrm{mg} \mathrm{kg}^{-1}$ in straw of zero till wheat. Similar results were recorded in the previous studies conducted by Akram et al. (2017); Cakmak et al. (2010).

In field trials, they were observed highest $\mathrm{Zn}$ concentration of 20 to $35 \mathrm{mg} \mathrm{kg}^{-1}$ in different crops with the soil and foliar application of $\mathrm{Zn}$. In another study, significantly higher content of zinc in wheat grain and straw was obtained with soil application of $\mathrm{Zn} \mathrm{SO}_{4}$ at $20 \mathrm{~kg} \mathrm{ha}^{-1}+$ foliar spray of $\mathrm{ZnSO}_{4}$ at $0.5 \%$ at crown root initiation and heading stages (Vora et al., 2019). While, significantly higher zinc content in straw (57.7 ppm) was recorded with soil application of $\mathrm{ZnSO}_{4}$ at $20 \mathrm{~kg} \mathrm{ha}^{-1}+0.5 \%$ foliar spray at milking and dough stages. $\mathrm{Zn}$ uptake was statistically more in all treatments as compared to control.

It was observed that $\mathrm{Zn}$ uptake by zero till wheat was same as $\mathrm{Zn}$ concentration in grain and straw. However, total $\mathrm{Zn}$ uptake was found highest (408.31 $\mathrm{g} \mathrm{ha}^{-1}$ ) with $\mathrm{T}_{13}$ and statistically at par with $\mathrm{T}_{10}\left(394.23 \mathrm{~g} \mathrm{ha}^{-1}\right)$ and $\mathrm{T}_{7}\left(374.55 \mathrm{~g} \mathrm{ha}^{-1}\right)$ treatment, respectively. It was due to higher $\mathrm{Zn}$ concentration in the respective $\mathrm{Zn}$ treatments in grain and straw. The lowest total 
Table 3: Effect of zinc application on grain quality parameters of zero till wheat (Pooled data of two years)

\begin{tabular}{lllllll}
\hline Treatments & $\begin{array}{l}\text { Sedimentation } \\
\text { value }(\mathbf{c c})\end{array}$ & $\begin{array}{l}\text { Dry gluten } \\
(\%)\end{array}$ & $\begin{array}{l}\text { Wet gluten } \\
(\%)\end{array}$ & $\begin{array}{l}\text { Hectoliter } \\
\text { weight }\left(\mathbf{k g ~ h} \mathbf{l}^{-1}\right)\end{array}$ & $\begin{array}{l}\text { Grain appearance } \\
\text { score (Max 10) }\end{array}$ & $\begin{array}{l}\text { Beta carotene } \\
\text { (PPM) }\end{array}$ \\
\hline $\mathrm{T}_{1}$ & 35.2 & 9.42 & 29.55 & 76.9 & 5.1 & 3.46 \\
$\mathrm{~T}_{2}$ & 36.9 & 9.54 & 31.27 & 77.1 & 5.2 & 3.55 \\
$\mathrm{~T}_{3}$ & 38.3 & 9.57 & 31.35 & 77.1 & 5.2 & 3.61 \\
$\mathrm{~T}_{4}$ & 41.3 & 9.63 & 31.51 & 77.3 & 5.2 & 3.70 \\
$\mathrm{~T}_{5}$ & 42.6 & 9.66 & 32.58 & 77.4 & 5.4 & 3.77 \\
$\mathrm{~T}_{6}$ & 43.9 & 10.09 & 32.65 & 77.7 & 5.3 & 3.87 \\
$\mathrm{~T}_{7}$ & 50.2 & 10.76 & 33.62 & 79.5 & 5.7 & 4.10 \\
$\mathrm{~T}_{8}$ & 47.9 & 10.21 & 32.89 & 78.4 & 5.5 & 3.91 \\
$\mathrm{~T}_{9}$ & 49.0 & 10.49 & 33.04 & 78.5 & 5.5 & 4.01 \\
$\mathrm{~T}_{10}$ & 51.0 & 10.78 & 33.62 & 79.7 & 5.7 & 4.18 \\
$\mathrm{~T}_{11}$ & 49.5 & 10.67 & 33.49 & 79.1 & 5.6 & 4.03 \\
$\mathrm{~T}_{12}$ & 50.1 & 10.71 & 33.51 & 79.2 & 5.6 & 4.12 \\
$\mathrm{~T}_{13}$ & 52.2 & 10.83 & 33.82 & 81.1 & 5.8 & 4.23 \\
$\mathrm{~S} . \mathrm{Em} \pm$ & 0.68 & 0.02 & 0.09 & 0.36 & 0.04 & 0.05 \\
LSD $(\mathrm{P}=0.05)$ & 2.0 & 0.08 & 0.20 & 1.06 & 0.1 & 0.14 \\
\hline
\end{tabular}

uptake was recorded in control due to lower concentration of $\mathrm{Zn}$ in the grain and straw. Similarly, significantly high zinc uptake (475.0 $\mathrm{g} \mathrm{ha}^{-1}$ was recorded with the soil application of $\mathrm{ZnSO}_{4}$ at $20 \mathrm{~kg} \mathrm{ha}^{-1}+0.5 \%$ foliar sprays at heading and milking stages by Sabir et al. (2015). A significant difference in average protein content was observed among different treatments of $\mathrm{Zn}$ by ElDahshouri etal. (2017).

The maximum average protein content $(12.53 \%)$ was produced by treatment $T_{13}$, which was statistically at par with $T_{10}$ $(12.40 \%)$ and $T_{7}(12.34 \%)$. However, the minimum mean protein content was recorded in control (11.49\%) with no Zn application (Table 2). Muhammad et al. (2019) recorded the highest protein content with application of $125 \% \mathrm{RDN}+\mathrm{ZnSO}_{4} 25 \mathrm{~kg} \mathrm{Zn} \mathrm{ha}^{-1}$ soil application $+\mathrm{ZnSO}_{4} 0.5 \%$ foliar spray, which might be due to the fact that soil and foliar application of zinc enhances nitrogen use efficiency in wheat grain and as nitrogen is the major component of amino acids, it leads to protein synthesis. Pallavi and Sudha (2017) recorded significantly highest protein content with combined soil $\left(20 \mathrm{~kg} \mathrm{Zn} \mathrm{ha}^{-1}\right)$ and foliar application $(0.5 \%$ through $\mathrm{ZnSO}_{4} \cdot 7 \mathrm{H}_{2} \mathrm{O}$ ) of $\mathrm{Zn}$ at heading and milking stage over control because micronutrient enhances accumulation of assimilates in grains (during the grain filling stage) leading to high protein content in seeds.

Increase in zinc dose led to concomitant increase in average protein content in wheat due to enhanced synthesis of indole acetic acid, chlorophyll formation and auxin metabolism. Cakmak et al. (2010) reported a close positive correlation between grain protein and Zn concentration. Akram et al. (2017) also reported that interaction effect of nitrogen and zinc increases the grain protein content in wheat. Various treatments of soil and foliar application of $\mathrm{Zn}$ significantly affected the sedimentation, dry and wet gluten content, and hectolitre weight, grain appearance and beta carotene values (Table 3). The highest value of all quality parameters was found with $T_{13}$ treatment and the lowest was recorded in control plot, whereas, significantly similar values were found with $T_{10}$ and $T_{7}$. Similarly, Muhammad et al. (2019) reported higher grain appearance score and hectoliter weight with $125 \% \mathrm{RDN}+\mathrm{ZnSO}_{4} 25 \mathrm{~kg} \mathrm{ha}^{-1}$ soil application $+\mathrm{ZnSO}_{4}$ 0.5\% foliar spray. The hectolitre weight and grain appearance score reflect the conditions during grain filling period of crop and as foliar application of zinc at milking and dough stage leads to bold, lustrous and attractive wheat grain, which ultimately enhances the value of hectolitre weight and grain appearance score.

The beta carotene value varied from 4.23 to $3.46 \mathrm{ppm}$ in grain of zero till wheat under various treatments, however, the highest was recorded in $T_{13}$ and lowest in $T_{1}$ treatment, respectively. The maximum value of beta carotene (3.64 ppm) was reported by Muhammad et al. (2019) with the application of $125 \% \mathrm{RDN}+25 \mathrm{kgha}^{-1}$ of $\mathrm{ZnSO}_{4}$ as soil application $+0.5 \%$ foliar spray of $\mathrm{ZnSO}_{4}$. The higher values of all parameters, may be due to essential role of $Z n$ on photosynthesis, chlorophyll, metabolism of starch formation and enzyme carbonic anhydrase accelerating carbohydrate formation, accumulation of suitable carbohydrate contents (Akgun et al., 2017; Soleymani et al., 2012). It also activates glutamic dehydrogenase enzyme, synthesis of RNA and DNA enhancing the quality, which are the main protein components of gluten accumulated at later stages of grain filling. The effect of $\mathrm{Zn}$ treatment was significant on sedimentation (24.17 cc) and wet gluten content $(31.56 \%)$ crude protein contents $(10.56 \%)$ of bran and flour of all cultivars. Zn application increased sedimentation, wet gluten content, protein, $\mathrm{Zn}$ content. The quality of wheat dry and wet gluten depends on their inherent chemical composition, which have a response function in various enzymatic activities in grain. 
It can be concluded from the findings of the present study, the soil and foliar application at later stages ameliorates $\mathrm{Zn}$ deficiency and improves the production and quality of zero till wheat. Therefore, the combined application of $\mathrm{Zn}$ (soil + foliar) with recommended fertilizer is more promising in improving, plant growth, yield and quality than other fertilization approaches.

\section{Acknowledgment}

We are thankful to the Faculty, Agriculture Khalsa College Amritsar and Dr. Avtar Singh Bimbraw, Senior Agronomist (Retd.), Punjab Agricultural University, Ludhiana for their coordination and facilitations to conduct this study.

\section{Add-on Information}

Authors' contribution: M. Singh: Experimental trial \& prepare research article; K.S. Sandhu: Guidance and manuscript correction.

Research content: The research content is original and has not been published elsewhere

\section{Ethical approval: NotApplicable}

Conflict of interest: The authors declare that there is no conflict of interest.

\section{Data from other sources: NotApplicable}

Consent to publish: All authors agree to publish the paper in Journal of Environmental Biology.

\section{References}

Afzal, U., M.S.I. Zamir, S.M.U. Din, A. Bilal, M. Salahuddin and S.I. Khan: Impact of different zinc application methods on yield and yield components of various wheat (Triticum aestivum L.) cultivars. American. J. Plant Sci., 8, 3502-3512 (2017).

Alloway, B.J.: Zinc in Soils and Crop Nutrition. Brussels: IZAPublications. (2004).

Alloway, B.J.: Zinc in Soils and Crop Nutrition. $2^{\text {nd }}$ Edn., International Fertilizer Industry Association, Paris (2008).

Akram, M. A., N. Depar and M.Y. Memon: Synergistic use of nitrogen and zinc to bio-fortify zinc in wheat grains. Eurasian J. Soil Sci., 6, 31926 (2017).

Axford, D.W.E., E.E. Mcenmott and D.G. Radman: Note on sodium dodecyl sulfate test of bread making quality comparison with Pelenske and Zeleny Test. Cereal. Chem., 56, 582-584 (1979).

Akgün, I., R. Karaman, F. Eraslan and M. Kayal: Effect of zinc on some grain quality parameters in bread and durum wheat cultivars. Unive. J. Agri. Res., 6, 260-265 (2017).

Cakmak, I.: Enrichment of cereal grains with zinc: Agronomic or genetic biofortification. Plant Soil, 302, 1-17 (2008).

Cakmak, I., W.H. Pfeiffer and B. Mcclafferty: Biofortification of durum wheat with zinc and iron. Cereal Chem., 1, 10-20 (2010).

Cakmak I., M. Kalayci, Y. Kaya, A. A. Torun, N. Aydin and Y Wang:
Biofortification and localization of zinc in wheat grain. J. Agri. Food Chem., 58, 9092-9102 (2010a).

El-Dahshouri, M.F., M.M. El-Fouly, R.K.M. Khalifa and H.M.A. El-Ghany: Effect of zinc foliar application at different physiological growth stages on yield and quality of wheat under sandy soil conditions. Agricultural Engineering International: CIGR J. Spe. Iss., 193-200 (2017).

Gomez, K.A. and A.A. Gomez: Statistical Procedures for Agricultural Research. $2^{\text {nd }}$ Edn. John Wiley \& Sons, New York (1984).

Imran, M. and A. Rehim: Zinc fertilization approaches for agronomic biofortification and estimated human bioavailability of zinc in maize grain. Archi. Agro. Soil. Sci., 63, 106-116 (2016).

Jackson, M.L.: Soil Chemical Analysis. New Delhi, Prentice Hall of India, Private limited (1967).

Kapil, U. and K. Jain: Magnitude of zinc deficiency amongst under five children in India. Indian J. Pediatr., 78, 1069-1072 (2011).

Muhammad, A., L.N. Dashora, J. Choudhary, S.S. Kadam and M. Moshin: Effect of varieties and nutrient management on quality and zinc biofortification of wheat (Triticum aestivum) Indian J. Agri. Sci., 89, 1472-1476 (2019).

Narwal, R.P., R.S. Malik and R.R. Dahiya: Addressing variations in a few nutritionally important micro-nutrients in wheat crop. Proceedings of $19^{\text {th }}$ World Congress of Soil Science, pp. 1-6 (2010).

Oztruk, L., M.A. Yazici, C. Yucel, A. Torun, C. Cekic, C. Bagci and A. Ozkan: Concentration and localization of zinc during seed development and germination in wheat. J. Plant Physiol., 128, 144-152 (2006).

Olsen, S.R., C.V. Cole, F.S. Waternade and L.A. Dean: Estimation of available phosphorous in soil by extraction with sodium bicarbonate. USDACirular 939 (1954).

Prasad, A.S.: Clinical, anti-inflammatory and antioxidant role of zinc. Exp. Gerintol., 43, 370-377 (2008).

Page, A.L., R.H. Miller and D.R. Keeney: Methods of soil analysis. Part 2. $2^{\text {nd }}$ Madison, Am. Soc. Agron., (1982).

Pallavi, V. and Sudha: Effect of soil and foliar application of zinc and iron on productivity and quality of wheat. J. Farm Sci., 1, 49-51 (2017).

Sabir, G.K., J. Peter, Dominy and A. Wiqar: Effect of $Z n$ as soil addition and foliar application on yield and protein content of wheat in alkaline soil. J. Natn. Sci. Found., 4, 303-312 (2015).

Shivay, Y.S., R. Prasad and A. Rahal: Relative efficiency of zinc oxide and zinc sulphate-enriched urea for spring wheat. Nutr. Cycl. Agroecosyst., 2, 259-264 (2008).

Soleymani, A. and M.H. Shahrajabian: The effects of Fe, $\mathrm{Mn}$ and $\mathrm{Zn}$ foliar application on yield, ash and protein percentage of forage sorghum in climatic condition of Esfahan. Int. J. Bio., 3, 12-20 (2012).

Subbiah, B.V. and G.L. Asija: A rapid procedure for the estimation of available nitrogen in soils. Curr. Sci., 25, 259-260 (1956).

Stein, A.J.: Global impacts of human mineral malnutrition. Plant Soil, 335, 133-154 (2010).

Takkar, P.N.: Micronutrient research and sustainable agricultural productivity in India. J. Indian Soc. Soil Sci., 44, 562-581 (1996).

Tiwana, N.S., N. Jerath, S.S. Ladhar, G. Singh, R. Paul, D.K. Dua and H.K. Parwana: State of environment; Punjab state council for science and technology, pp -243 (2007).

Vora, V.D., K.K. Kanzaria, P.D. Vekaria, V.L. Modhyadiya, G.B. Vekaria and D.S. Hirpara: Effect of zinc fertilization on wheat yield under sandy loam soil. J. Pharmacognosy. phytochem., 3, 2086-2088 (2019)

Welch, R.M.: Biotechnology, biofortification and global health. Food Nutr. Bull., 26, 419-421 (2005). 